\title{
Genetically distinct colour morphs of European perch Perca fluviatilis in Lake Constance differ in susceptibility to macroparasites
}

\author{
S. Roch*†, J. Behrmann-Godel $\$$ ANd A. BrinKer* \\ *Fisheries Research Station Baden-Württemberg, Argenweg 50/1, 88085 Langenargen, \\ Germany and $\$$ Limnological Institute of the University of Konstanz, Mainaustraße 252, 78464 \\ Konstanz, Germany
}

\begin{abstract}
The unusual yellow-finned morph of European perch Perca fluviatilis found in Lake Constance suffers more severely from macroparasite infections, including the tapeworm Triaenophorus nodulosus and the gill worm Ancyrocephalus percae, than conspecifics elsewhere. Microsatellite analysis of yellow-finned $P$. fluviatilis and red-finned variant recently discovered in Lake Constance revealed significant genetic differentiation. Red-finned $P$. fluviatilis and fish with mixed fin colour, suggested backcrosses between red and yellow-finned colour morphs, exhibit better resilience to parasite infection, suggesting that the inability of the yellow-finned morph to reject macroparasites may have a genetic basis.
\end{abstract}

Key words: Ancyrocephalus percae; Cestoda; isthmus; Monogenea; Triaenophorus nodulosus; yellow fins.

At around $535 \mathrm{~km}^{2}$, Lake Constance $\left(47^{\circ} 30^{\prime} \mathrm{N} ; 09^{\circ} 30^{\prime} \mathrm{E}\right)$ is one of the largest lakes in Europe (Petri, 2006). The large commercial fisheries on the lake target mainly whitefish, but catches of the European perch Perca fluviatilis (L. 1758) are also economically important (Eckmann \& Rösch, 1998). Perca fluviatilis in Lake Constance are affected by various endo and ectoparasites (Balling \& Pfeiffer, 1997a, $b, c, d$; Behrmann-Godel, 2013), including the extensively studied tapeworm Triaenophorus nodulosus (Dieterich \& Eckmann, 2000). Plerocercoids of T. nodulosus utilize $P$. fluviatilis as second intermediate hosts, within which they infest the liver and are normally encapsulated after some weeks (Kuperman, 1973). Previous studies indicate that the established $P$. fluviatilis stock of Lake Constance is unusually susceptible to infection by T. nodulosus. Both prevalence and intensity of infections are higher than are usually seen in other circumpolar populations, and T. nodulosus in Lake Constance P. fluviatilis attain longer body length and diameter than in conspecific hosts elsewhere

$\dagger$ Author to whom correspondence should be addressed. Tel.: +49 75439308 336; email: Samuel.Roch@lazbw.bwl.de 
TABLE I. Differences in several aspects of Triaenophorus nodulosus and Ancyrocephalus percae infestation of adult yellow-finned Perca fluviatilis from Lake Constance compared with conspecifics from other lakes, found in the literature

\begin{tabular}{|c|c|c|c|c|}
\hline & \multicolumn{2}{|c|}{ T. nodulosus } & \multicolumn{2}{|c|}{ A. percae } \\
\hline & Lake Constance $^{\mathrm{a}}$ & Literature & $\begin{array}{c}\text { Lake } \\
\text { Constance }^{\mathrm{b}}\end{array}$ & Literature \\
\hline Parasite length (mm) & $\begin{array}{c}46 \pm 38(\text { mean } \pm \text { S.D. }) \\
\text { (maximum: } 300)\end{array}$ & $10-100^{b, c}$ & $0 \cdot 8-3 \cdot 7$ & $1 \cdot 0-1 \cdot 8^{\mathrm{e}}$ \\
\hline Prevalence $(\%)$ & 94 & $10-91^{\mathrm{b}, \mathrm{c}, \mathrm{f}-\mathrm{k}}$ & 85 & $1 \cdot 1^{\mathrm{g}}$ \\
\hline Mean intensity & $4 \cdot 2$ & $1 \cdot 5-4 \cdot 3 \mathrm{~g}, \mathrm{j}, \mathrm{k}$ & $12-53$ & $1 \cdot 8^{\mathrm{g}}$ \\
\hline Maximum intensity & 52 & $3-28^{\mathrm{b}, \mathrm{f}-\mathrm{h}, \mathrm{j}, \mathrm{k}}$ & 215 & $5^{\mathrm{g}}$ \\
\hline Infestation site & Liver & Liver $^{\mathrm{c}, \mathrm{d}, \mathrm{f}-\mathrm{k}}$ & Isthmus $\mathrm{s}^{\mathrm{d}, 1}$ & Gills $\mathrm{s}^{\mathrm{e}, \mathrm{g}, \mathrm{m}, \mathrm{n}}$ \\
\hline Rare sites & Other viscera, fillet & Other viscera ${ }^{\mathrm{b}, \mathrm{f}, \mathrm{g}}$ & & \\
\hline Damage & Severe & Moderate ${ }^{b, h}$ & Severe & Mild ${ }^{g}$ \\
\hline
\end{tabular}

a Brinker \& Hamers (2007); ${ }^{\mathrm{b}}$ Kuperman (1973); ${ }^{\mathrm{c}}$ Hoffmann et al. (1986); ${ }^{\mathrm{d}}$ this study; ${ }^{\mathrm{e}}$ Ergens (1966); ${ }^{\mathrm{f}}$ Chubb (1964); ${ }^{\mathrm{g}}$ Andrews (1979); ${ }^{\mathrm{h}}$ Lucky \& Navratil (1984); ${ }^{\mathrm{i}}$ Negele et al. (1990); ${ }^{\mathrm{j} M o r o z i n s k a-G o g o l}$ (2013); ${ }^{\mathrm{k}}$ Dezfuli et al. (2014); ${ }^{\mathrm{l} B e h r m a n n-G o d e l ~ e t ~ a l . ~(2014) ; ~}{ }^{\mathrm{m}}$ Bylund \& Pugachev (1989); ${ }^{\mathrm{n}}$ Morozinska-Gogol (2008).

(Table I). Severely infected individuals exhibit markedly reduced growth, 16\% down on uninfected conspecifics, and risk of mortality following spawning is significantly higher (Brinker \& Hamers, 2007). Molzen (2005) observed a 20\% reduction in fecundity of infected $P$. fluviatilis in Lake Constance, correlated with parasite-induced liver pathology.

The recent arrival in Lake Constance of an invasive gill worm of the genus Ancyrocephalus (Monogenea) prompted morphological and genetic studies that identified the species as Ancyrocephalus percae (Behrmann-Godel et al., 2014). This parasite has a pan-European distribution (Andrews, 1979; Bylund \& Pugachev, 1989; Morozinska-Gogol, 2008), and is not generally known for causing severe harm to its P. fluviatilis hosts (Andrews, 1979). Normally, A. percae infects only the gills of P. fluviatilis (Ergens, 1966) but in Lake Constance the adult parasites appear to actively migrate from the gills to the isthmus, where they cause deep, oval to round lesions (Behrmann-Godel et al., 2014). In the most severe cases, the isthmus is perforated or even completely destroyed. This new target site and the resulting damage in P. fluviatilis hosts are, as far as is known, unique to Lake Constance (Table I). High intensity infections are normally quite unusual for A. percae (Andrews, 1979), but in afflicted Lake Constance $P$. fluviatilis, the number of parasites found infesting wounds on the isthmus can exceed 200 individuals (Behrmann-Godel et al., 2014).

Historically, P. fluviatilis in Lake Constance have been characterized by yellow fin colour [Fig. 1(a)]. Recently, however, a red-finned morph has been observed. In laboratory studies, attempts to modify fin colour by supplementing dry food with carotenoids, resulted in only a slight increase in intensity of the yellow colouration, the fin colour could not be changed to red (R. Eckmann, unpubl. data). In addition to fin colour, the two morphs also exhibit differences in body shape and colour pattern of the body. Mapping the distribution of the new red-finned morph requires a lake-wide study, yet to be carried out, and their life cycle has not yet been examined. Since in 2013, 

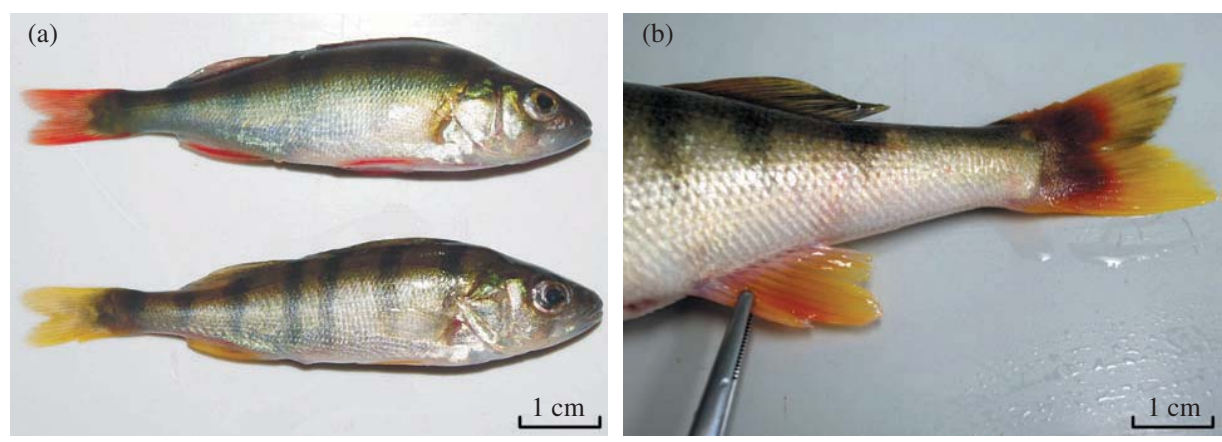

FIG. 1. Different fin colour morphs of Perca fluviatilis in Lake Constance. (a) Young-of-the year fish with red and yellow fin colour. (b) Adult yellow-finned fish with red patches in its fins (mixed colour morph).

however, adult fish have been recorded, with clearly defined red areas in their yellow fins, suggesting that cross-breeding between yellow- and red-finned morphs may be taking place [Fig. 1(b)]. These red patches were not related to infection or disease. In Langenargen marina (a marina located on the north shore of Lake Constance, Germany), juvenile $P$. fluviatilis with red fins can be caught on a regular basis. Early examinations of the A. percae infestation in 2012 indicated that yellow-finned P. fluviatilis are distinctly more affected by the gill parasite than their red-finned conspecifics. Taken together, these observations lead to the hypothesis that yellow-finned $P$. fluviatilis of Lake Constance lack certain genetic adaptations to cope with infections by endo and ecto-macroparasites, which consequently exhibit extraordinary virulence in these hosts.

For genetic characterization of the yellow, red and mixed fin colour P. fluviatilis, nine microsatellite loci in two multiplexes were analysed, using a Type-it kit (Qiagen; www.qiagen.com). The first batch contained the markers PflaL2, Svi17, PflaL5, SviL7, Svi6 and PflaL10 and the second batch contained the markers Svi18, PflaL4 and PflaL9 (Borer et al., 1999; Wirth et al., 1999; Leclerc et al., 2000). The PCR cycle was $95^{\circ} \mathrm{C}$ for $5 \mathrm{~min}$, then 27 rounds using a cycle at $95^{\circ} \mathrm{C}$ for $30 \mathrm{~s}, 56^{\circ} \mathrm{C}$ for $90 \mathrm{~s}$ and $72^{\circ} \mathrm{C}$ for $30 \mathrm{~s}$, finishing with $60^{\circ} \mathrm{C}$ for $30 \mathrm{~min}$. The two batches were fragment analysed on an ABI 3130 genetic analyser. Allele calling was carried out automatically using GeneMapper 4.0 (Applied Biosystems; www.appliedbiosystems.com) software, and controlled visually. Microsatellite data was checked for genotyping errors using Micro-Checker 2.2.3 (Van Oosterhout et al., 2004). A total of 41 red-finned, 23 yellow-finned and 11 with mixed fin colour individuals of mixed age $P$. fluviatilis were successfully analysed, with no indication for large allele dropout, stuttering errors or null alleles. Possible deviations from the Hardy-Weinberg equilibrium (HWE) were analysed by comparing the number of expected and observed heterozygotes in the microsatellite data using Arlequin 3.5 software (Excoffier \& Lischer, 2010). Deviations from HWE were found at five loci for red-finned $P$. fluviatilis, indicating further substructuring of these individuals, whereas none was found for the yellow-finned morphs. Heterozygosity and fixation indices $\left(F_{\mathrm{ST}}\right)$ were also calculated using Arlequin. The programme Structure 2.3.4 (Pritchard et al., 2000) was used to visualize detailed population structure; Structure Harvester 0.6.8 (Earl \& vonHoldt, 2012) was used to implement the Evanno method (Evanno et al., 2005) to find the most probable number of clusters $K$. 
The data revealed significant population differentiation (after Bonferroni correction) between yellow and red-finned morphs (pair-wise $F_{\mathrm{ST}}$ value of $0.08, P<0.001$; permutation test as implemented in Arlequin). Although only 11 individuals of the mixed-colour morph were caught and analysed, they differed significantly (after Bonferroni correction) from the red-finned morph (pair-wise $F_{\mathrm{ST}}$ value of $0 \cdot 06$, $P<0.001$; permutation test as implemented in Arlequin). There was no apparent genetic differentiation in pair-wise comparisons of mixed colour and yellow-finned morphs (pair-wise $F_{\mathrm{ST}}$ value of $0.0015, P>0.05$; permutation test as implemented in Arlequin). Yellow-finned and red-finned $P$. fluviatilis appeared as two different groups in the Bayesian cluster analysis (Fig. 2) and a conclusion of $K=2$ populations was strongly supported by the Evanno method. All but one yellow-finned individual exhibited high posterior probabilities for the yellow genotype. While most red-finned individuals yielded highest posterior probabilities for the red genotype, some also indicated high posterior probabilities for the yellow genotype or appeared intermediate. Nine of the individuals with mixed coloured fins exhibited high posterior probabilities for yellow and two for red genotype (Fig. 2). These results suggest that the red-finned group does not represent a pure genetic cluster. It is not known whether the red-finned morph has its evolutionary origin in Lake Constance, and thus it is impossible to define two pure reference populations for the purpose of exact hybrid status determination such as with NewHybrids analyses (Anderson \& Thompson, 2002). An analysis without reference populations was inconclusive. It, therefore, remains unclear from the genetic information available whether or not mixed coloured $P$. fluviatilis might be backcross hybrids. The $F_{\mathrm{ST}}$ values and structural results, however, suggest that these fish are not F1 hybrids between red and yellow-finned $P$. fluviatilis, as this would have yielded intermediate $F_{\mathrm{ST}}$ values. In the light of all available information, the most probable explanation is that the mixed fin colour individuals caught in this study represent late backcrosses between red and yellow-finned morphs.

The situation existing in Lake Constance offered an excellent opportunity for comparing the parasite responses of local yellow-finned $P$. fluviatilis and the recently arrived red-finned morph. Both colour morphs are found in the same habitat, where they are exposed to both the established T. nodulosus, and the recently introduced A. percae. Between July and October, young-of-the-year (YOY) P. fluviatilis were sampled once a week, using sinking nets or electrofishing in the Langenargen (Germany) marina area. A total of 300 yellow-finned and 109 red-finned YOY were caught in the same habitat. Adult fish (2 years and older) were sampled once every 2 weeks, using a bottom net, with mesh sizes of 28 and $32 \mathrm{~mm}$, at 10-30 m depth near Langenargen. Adult red-finned $P$. fluviatilis $(n=15)$ and adult mixed colour morphs $(n=13)$ were much less common than adult yellow-finned fish $(n=290)$. The age of each individual adult P. fluviatilis was established by examination of the opercula bones (Le Cren, 1947). The livers of all fish were examined for signs of infection with T. nodulosus, according to Brinker \& Hamers (2007), and variables of A. percae and T. nodulosus infestation were measured following Bush et al. (1997). Differences in the prevalence and intensity of infestation between colour morphs were analysed statistically using Fisher's exact tests and Wilcoxon tests, respectively, with significance levels set at 0.05 (Bosch, 1993). Welch tests were applied to test differences in variance between individual samples (Welch, 1938). The statistical analyses were conducted using JMP Pro 11.2.1 (SAS; www.jmp.com). 


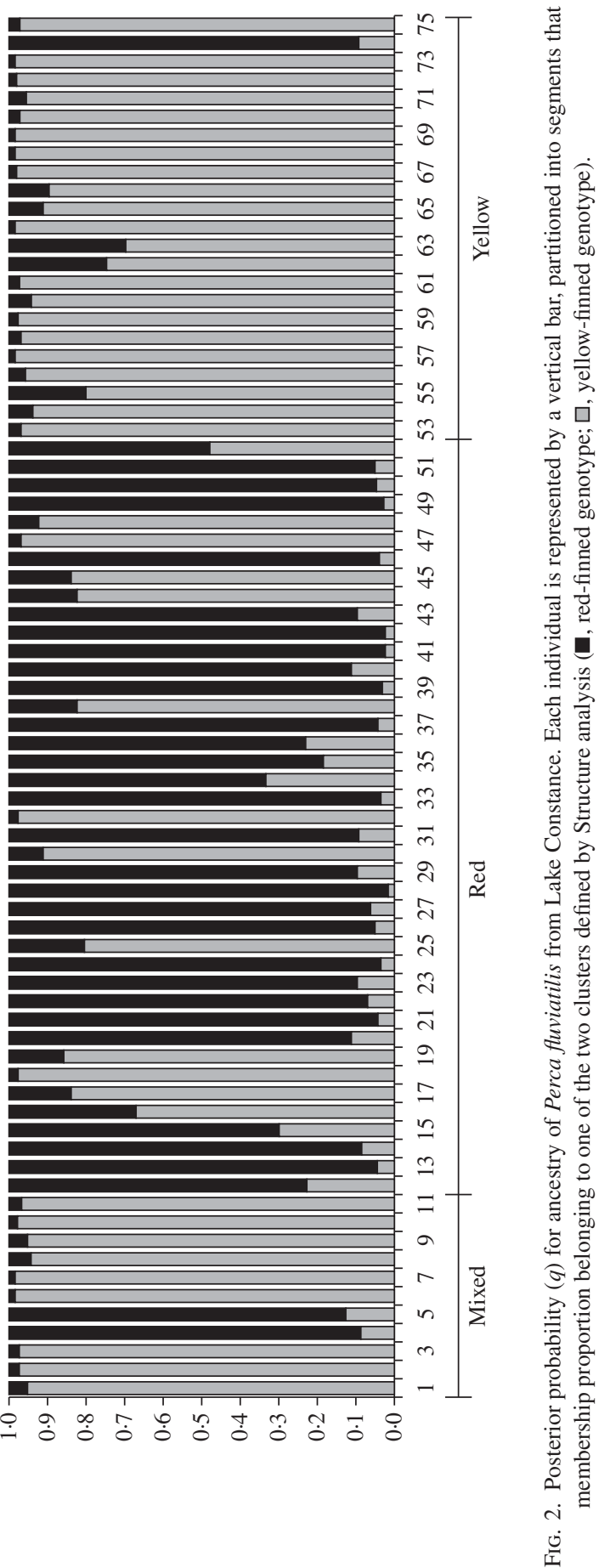



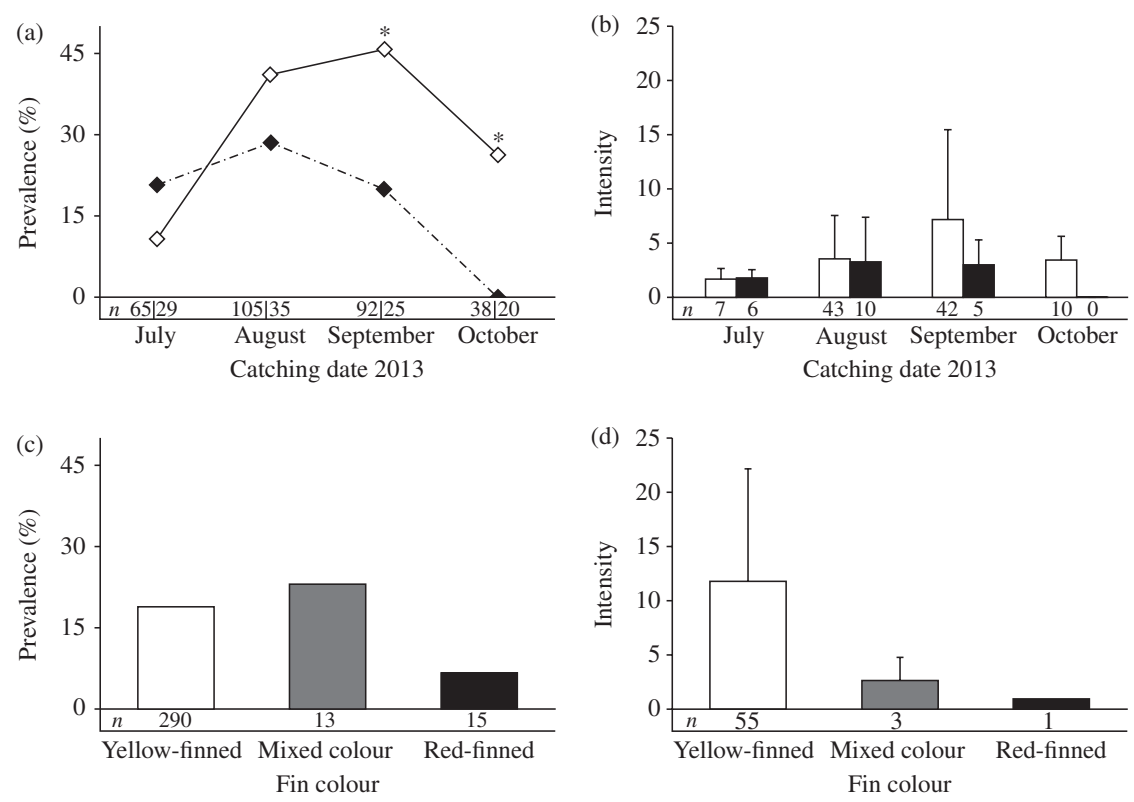

FIG. 3. (a, b) Infestation of young of the year yellow-finned $(\diamond, \square)$ and red-finned $(\bullet, \square)$ morph Perca fluviatilis and (c, d) adult (2 years and older) yellow-finned $(\square)$, mixed-colour $(\square)$ and red-finned $(\square)$ morph $P$. fluviatilis with Ancyrocephalus percae in Lake Constance, 2013. (a, c) Per cent prevalence. (b, d) Mean + S.D. intensity. Numbers indicate sample size [n, sample size; in (a) yellow-finnedlred-finned]. *, Statistically significant differences between colour morphs (prevalence, Fisher's exact test; intensity, Wilcoxon test; $P<0.05)$.

The results show that YOY P. fluviatilis arrive in the littoral zone in early summer uninfected with $A$. percae, but that infection sets in rapidly thereafter, reaching peak prevalence of $45.7 \%$ in September [Fig. 3(a)]. Infection among red-finned YOY fish increased much more slowly, peaking at $28.6 \%$ in August and declining thereafter. By October, prevalence among red-finned YOY had returned to zero. In contrast, by October, $26 \cdot 3 \%$ of the YOY yellow-finned P. fluviatilis were still infected, a value comparable to the peak prevalence seen in the red-finned morph. These differences in prevalence between the two colour morphs were statistically significant in September and October (Fisher's exact test, d.f. $=1, P<0 \cdot 05$ ).

The intensity of $A$. percae infection in YOY yellow-finned $P$. fluviatilis also increased in mid-summer, but remained stable in red-finned fish [Fig. 3(b)]. The maximum intensity for yellow-finned hosts was $45 \mathrm{~A}$. percae individuals per fish, whereas for red-finned hosts it was only 14 parasites. Unfortunately, however, these differences could not be confirmed statistically (Wilcoxon test, d.f. $=1, P>0.05$ ). The test power was low as variability in the number of parasites found per individual was high. In September, when the greatest differences in infection intensities between the fin colour morphs were observed, there was a significant difference in variance (Welch test, $F_{1,20}=6.33, P<0.05$ ), indicating clear differences in the degree and type of infection between yellow and red-finned $P$. fluviatilis in Lake Constance.

As all YOY fish shared the same shallow-water habitat with each other and with older conspecifics (Eckmann \& Rösch, 1998), and A. percae actively seize their hosts 
(Behrmann-Godel et al., 2014), both colour morphs face the same risk of infection. The defence mechanisms in affected tissues of host fish play an important role in resisting infection, particularly with respect to gyrodactylid parasites (Buchmann \& Bresciani, 1997). The immune responses of YOY fish, however, may be incompletely developed (Uribe et al., 2011), leading to a relatively high prevalence of infection. The observed reduction in infections of YOY red-finned $P$. fluviatilis in late summer is evidence of successful rejection of A. percae, leading to zero infection in October. In contrast, yellow-finned fish appear incapable of raising an appropriate defence against the parasite. The exceptionally high infection intensities observed in some yellow-finned hosts from Lake Constance corroborate the hypothesis outlined above.

Supporting results were found in adult $P$. fluviatilis (2 years and older). Due to the small proportions of red-finned and mixed-colour morphs in catches, a seasonal comparison of infestation variables was not possible. For 15 adult red-finned fish examined, however, only one individual was infected by A. percae [Fig. 3(c)], and in this fish only a single parasite was found. It can be concluded that it resembles an incidental infestation. Some differences in infection intensity were recorded between yellow-finned and mixed colour fish [Fig. 3(d)], but the results were not statistically significant (Wilcoxon test, d.f. $=1, P>0 \cdot 05$ ). Of special interest is the mixed colour morph of $P$. fluviatilis. If the individuals analysed in this study are backcrosses between yellow and red-finned morphs, as indicated by the genetic analysis, the data suggests that some part of the A. percae resistance seen in red-finned fish is transmitted to backcross offspring [Fig. 3(c), (d)].

The hypothesis that the two colour morphs of P. fluviatilis in Lake Constance differ in their susceptibility to parasite infestation finds further support in the prevalence data for T. nodulosus infection (Fig. 4). Red-finned YOY fish were significantly less affected by $T$. nodulosus than young yellow-finned fish. (Fisher's exact test, d.f. $=1$, $P<0 \cdot 05)$. The pattern is repeated in adult fish, where nearly all yellow-finned individuals were infested by plerocercoids, while fish with mixed fin colour were significantly less affected, and red-finned individuals exhibited the lowest prevalence (Fisher's exact test, d.f. $=1, P<0.001)$. Previous work has shown that yellow-finned $P$. fluviatilis from Lake Constance suffer higher prevalences of T. nodulosus infection and grows much larger in the liver of yellow-finned hosts. Plerocercoids do not normally grow larger than 10-100 mm in the liver of hosts (Kuperman, 1973; Hoffmann et al., 1986), but those in Lake Constance are known to achieve lengths up to $300 \mathrm{~mm}$ (Brinker \& Hamers, 2007). At around 95\%, the prevalence of infection in yellow-finned Lake Constance P. fluviatilis is also one of the highest recorded in the literature (Brinker \& Hamers, 2007). The reason for this exaggerated virulence is unclear. Extensive chemotaxis assays (Falk et al., 1980) reveal a significant positive chemotactic reaction of $P$. fluviatilis leucocytes in response to both T. nodulosus and A. percae, but no differences were observed between the different $P$. fluviatilis colour morphs. Intensive diet studies with the red-finned morph should now be carried out, examining possible preferences for certain copepod species. As first intermediate hosts for T. nodulosus, these prey items may account for differences in prevalence and intensity of infection in different $P$. fluviatilis colour morphs. Due to the ongoing reoligotrophication of Lake Constance, copepods dominate the zooplankton community (IGKB, 2011). Especially abundant are Cyclops vicinus, Cyclops abyssorum, Eudiaptomus gracialis and Mesocyclops leuckarti (Stich et al., 2005), which all could serve as first intermediate hosts (Kuperman, 1973). The declining zooplankton abundance of oligotrophic 


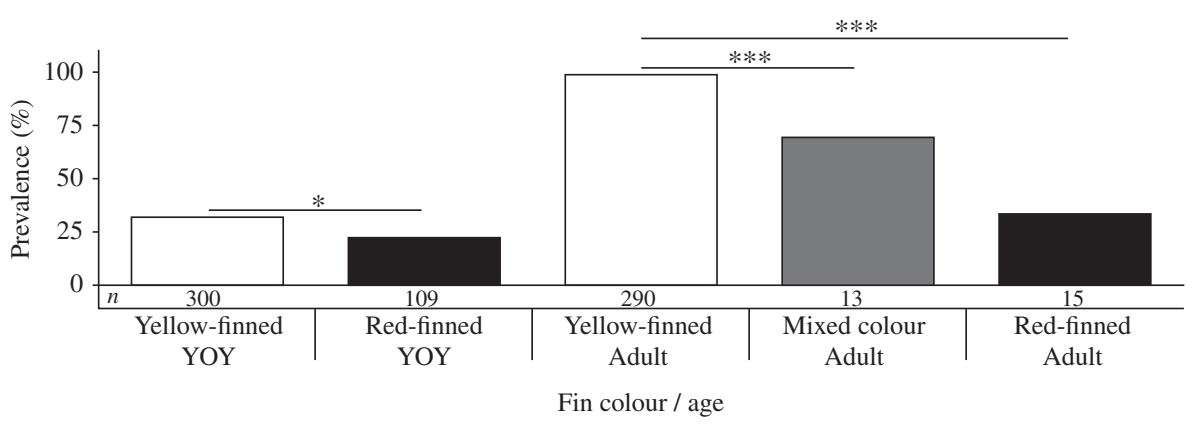

FIG. 4. Infestation of young of the year (YOY) and adult Perca fluviatilis [yellow-finned ( $\square$ ), mixed colour ( $\square$ ) and red-finned (-) morph] with Triaenophorus nodulosus in Lake Constance, 2013. Prevalence is given as a percentage value. $n$, sample size. *, Statistically significant differences between colour morphs (Fisher's exact test, $* P<0 \cdot 05 ; * * * P<0 \cdot 001)$.

lakes increases the percentage of copepods infected with T. nodulosus (Lucky \& Navratil, 1984) and thereby also increases the chances of any P. fluviatilis colour morph ingesting infected prey. Because all morphs share the same habitat, major differences in the copepod composition of their diet are thought to be unlikely.

In conclusion, these findings show clear differences between the yellow-finned and red-finned morphs of Lake Constance $P$. fluviatilis, with distinctions not only in fin colour, but also in their ability to handle macroparasite infections. The yellow-finned morph in Lake Constance appears unable to muster an adequate defence to either $A$. percae or T. nodulosus, resulting in a higher prevalence and intensity of infestation and targeting of the isthmus as a new infection site by A. percae (Table I). Both macroparasites are able to cause dramatic pathologic damage to yellow-finned P. fluviatilis, with severe ecological and economical effects on their stocks in Lake Constance. The mixed colour $P$. fluviatilis morph, with red patches in its yellow fins, appears intermediate between yellow- and red-finned individuals in terms of susceptibility to infection by both macroparasites, and may represent backcrosses between the two colour morphs, exhibiting traits from both parents. More genetic studies are needed to properly understand the relationship between the different colour morphs. These results raise fascinating questions, not least: (1) Why does the yellow-finned genotype remain so successful in Lake Constance, a waterbody surrounded and connected to systems with only red-finned P. fluviatilis? (2) How do the genotypes differ immunologically? and (3) What are the implications of A. percae selecting a new target tissue?

We would like to thank R. Eckmann for supporting information and helpful comments on the article, A. Revermann, N. Knöpfler and G. Knöpfler for the provision of fish and J. Rößle for her work on the microsatellite analysis. We also thank A.-J. Beer for the language correction and improvement of the manuscript, and the two reviewers for their valuable feedback.

\section{References}

Anderson, E. C. \& Thompson, E. A. (2002). A model-based method for identifying species hybrids using multilocus genetic data. Genetics 160, 1217-1229.

Andrews, C. (1979). Host specificity of the parasite fauna of perch Perca fluviatilis L. from the British Isles, with special reference to a study at Llyn Tegid (Wales). Journal of Fish Biology 15, 195-209. doi: 10.1111/j.1095-8649.1979.tb03583.x 
Balling, T. E. \& Pfeiffer, W. (1997a). Frequency distributions of fish parasites in the perch Perca fluviatilis L. from Lake Constance. Parasitology Research 83, 370-373. doi: $10.1007 / \mathrm{s} 004360050264$

Balling, T. E. \& Pfeiffer, W. (1997b). Location-dependent infection of fish parasites in Lake Constance. Journal of Fish Biology 51, 1025-1032. doi: 10.1006/jfbi.1997.0507

Balling, T. E. \& Pfeiffer, W. (1997c). The parasitism of fish from Lake Constance - a comparison of present and earlier data. Parasitology Research 83, 793-796. doi: $10.1007 / \mathrm{s} 004360050341$

Balling, T. E. \& Pfeiffer, W. (1997d). Seasonal differences in infestation of the perch Perca fluviatilis L. from Lake Constance with digenean trematodes. Parasitology Research 83, 789-792. doi: 10.1007/s004360050340

Behrmann-Godel, J. (2013). Parasite identification, succession and infection pathways in perch fry (Perca fluviatilis): new insights through a combined morphological and genetic approach. Parasitology 140, 509-520. doi: 10.1017/s0031182012001989

Behrmann-Godel, J., Roch, S. \& Brinker, A. (2014). Gill worm Ancyrocephalus percae (Ergens 1966) outbreak negatively impacts the Eurasian perch Perca fluviatilis L. stock of Lake Constance, Germany. Journal of Fish Diseases 37, 925-930. doi: 10.1111/jfd.12178

Borer, S. O., Miller, L. M. \& Kapuscinski, A. R. (1999). Microsatellites in walleye Stizostedion vitreum. Molecular Ecology 8, 336-338.

Bosch, K. (1993). Statistik-Taschenbuch. München, Wien: R. Oldenbourg.

Brinker, A. \& Hamers, R. (2007). Evidence for negative impact of plerocercoid infection of Triaenophorus nodulosus on Perca fluviatilis L. stock in upper Lake Constance, a water body undergoing rapid reoligotrophication. Journal of Fish Biology 71, 129-147. doi: 10.1111/j.1095-8649.2007.01475.x

Buchmann, K. \& Bresciani, J. (1997). Microenvironment of Gyrodactylus derjavini rainbow trout Oncorhynchus mykiss: association between mucous cell density in skin and site selection. Parasitology Research 84, 17-24. doi: 10.1007/s004360050350

Bush, A. O., Lafferty, K. D., Lotz, J. M. \& Shostak, A. W. (1997). Parasitology meets ecology on its own terms: Margolis et al. revisited. Journal of Parasitology 83, 575-583. doi: $10.2307 / 3284227$

Bylund, G. \& Pugachev, O. N. (1989). Monogenea of fish in Finland (Dactylogyridae, Ancyrocephalidae, Tetraonchidae). In Parasites of Freshwater Fishes of North-West Europe: Materials of the International Symposium within the Program of the Soviet Finnish Cooperation 10-14 January 1988 (Bauer, O. N., ed.), pp. 20-30. Petrozavodsk: Institute of Biology \& Zoological Institute, USSR Academy of Sciences.

Chubb, J. C. (1964). Observations on the occurrence of the plerocercoids of Triaenophorus nodulosus (Pallas, 1781) (Cestoda: Pseudophyllidea) in the perch Perca fluviatilis L. of Llyn Tegid (Bala Lake), Merionethshire. Parasitology 54, 481-491. doi: 10.1017/s0031182000082524

Dezfuli, B. S., Giari, L., Lorenzoni, M., Manera, M. \& Noga, E. J. (2014). Perch liver reaction to Triaenophorus nodulosus plerocercoids with an emphasis on piscidins 3, 4 and proliferative cell nuclear antigen (PCNA) expression. Veterinary Parasitology 200, 104-110. doi: $10.1016 /$ j.vetpar.2013.11.023

Dieterich, A. \& Eckmann, R. (2000). The infection of Eurasian perch Perca fluviatilis L. with Triaenophorus nodulosus (Pallas) plerocercoids in Lake Constance (Germany). Bulletin of the European Association of Fish Pathologists 20, 34-39.

Earl, D. \& vonHoldt, B. (2012). STRUCTURE HARVESTER: a website and program for visualizing STRUCTURE output and implementing the Evanno method. Conservation Genetics Resources 4, 359-361. doi: 10.1007/s12686-011-9548-7

Eckmann, R. \& Rösch, R. (1998). Lake Constance fisheries and fish ecology. Advances in Limnology 53, 285-301.

Ergens, R. (1966). Revision of the helminthofauna of fishes in Czechoslovakia III. Genus Ancyrocephalus (s.l.) Creplin, 1839 (Monogenoidea Dactylogyridae). Folia Parasitolologica [Praha] 13, 28-35.

Evanno, G., Regnaut, S. \& Goudet, J. (2005). Detecting the number of clusters of individuals using the software STRUCTURE: a simulation study. Molecular Ecology 14, 2611-2620. doi: 10.1111/j.1365-294X.2005.02553.x 
Excoffier, L. \& Lischer, H. E. L. (2010). Arlequin suite ver 3.5: a new series of programs to perform population genetics analyses under Linux and Windows. Molecular Ecology Resources 10, 564-567. doi: 10.1111/j.1755-0998.2010.02847.x

Falk, W., Goodwin, R. H. \& Leonard, E. J. (1980). A 48-well micro chemotaxis assembly for rapid and accurate measurement of leukocyte migration. Journal of Immunological Methods 33, 239-247. doi: 10.1016/0022-1759(80)90211-2

Hoffmann, R. W., Meder, J., Klein, M., Osterkorn, K. \& Negele, R. D. (1986). Studies on lesions caused by plerocercoids of Triaenophorus nodulosus in some fish of an alpine lake, the Konigssee. Journal of Fish Biology 28, 701-712. doi: 10.1111/j.1095-8649.1986.tb 05204.X

IGKB (2011). Limnologischer Zustand des Bodensees Jahresbericht der Internationalen Gewässerschutzkomission 39 (in German).

Kuperman, B. I. (1973). Tapeworms of the Genus Triaenophorus, Parasites of Fishes. New Delhi: Amerind Publishing Co. Pvt. Ltd.

Le Cren, E. D. (1947). The determination of the age and growth of the perch (Perca fluviatilis) from the opercular bone. Journal of Animal Ecology 16, 188-204.

Leclerc, D., Wirth, T. \& Bernatchez, L. (2000). Isolation and characterization of microsatellite loci in the yellow perch (Perca flavescens), and cross-species amplification within the family Percidae. Molecular Ecology 9, 995-997. doi: 10.1046/j.1365-294x.2000. 00939-3.x

Lucky, Z. \& Navratil, S. (1984). Parasitic Diseases of the Perch (Perca fluviatilis) in Detention Reservoirs of the Morava River Basin. Acta Veterinaria Brno 53, 81-90. doi: 10.2754/avb198453010081

Molzen, B. U. (2005). Die Auswirkung des Befalls mit Plerocercoiden des Hechtbandwurms (Triaenophorus nodulosus (P.)) auf den Flussbarsch (Perca fluviatilis L.) im Bodensee-Obersee. Doctoral Dissertation, Ludwig-Maximilians-Universität, München, Germany. Available at http://edoc.ub.uni-muenchen.de/4999/1/Molzen_Bettina_Ulla. pdf/

Morozinska-Gogol, J. (2008). A check-list of parasites of percid fishes (Actinopterygii: Percidae) from the estuaries of the Polish coastal zone. Helminthologia 45, 196-203. doi: 10.2478/s11687-008-0039-7

Morozinska-Gogol, J. (2013). Parasite communities of European perch, Perca fluviatilis L. (Actinopterygii: Perciformes: Percidae) from Lake Lebsko (Central Coast, Poland). Annals of Parasitology 59, 89-98.

Negele, R. D., Leuner, E., Bohl, E. \& Leyerer, R. (Eds) (1990). Ökoparasitologische untersuchungen an fischen des Königssees, Obersees und Grünsees. Fischbiologie des Königssees - Fischereibiologie und Parasitologie (Forschungsbericht 21/1990). Berchtesgaden: Nationalparkverwaltung Berchtesgaden.

Petri, M. (2006). Water quality of Lake Constance. In Handbook of Environmental Chemistry (Hutzinger, O., ed), pp. 127-138. Berlin: Springer-Verlag.

Pritchard, J. K., Stephens, M. \& Donnelly, P. (2000). Inference of population structure using multilocus genotype data. Genetics 155, 945-959.

Stich, H. B., Pfeiffer, M. \& Maier, G. (2005). Zooplankton communities in a large prealpine lake, Lake Constance: comparison between the Upper and the Lower Lake. Journal of Limnology 64, 129-138.

Uribe, C., Folch, H., Enriquez, R. \& Moran, G. (2011). Innate and adaptive immunity in teleost fish: a review. Veterinární Medicína 56, 486-503.

Van Oosterhout, C., Hutchinson, W. F., Wills, D. P. M. \& Shipley, P. (2004). MICRO-CHECKER: software for identifying and correcting genotyping errors in microsatellite data. Molecular Ecology Notes 4, 535-538. doi: 10.1111/j.1471-8286.2004.00684.x

Welch, B. L. (1938). The significance of the difference between two means when the population variances are unequal. Biometrika 29, 350-362. doi: 10.2307/2332010

Wirth, T., Saint-Laurent, R. \& Bernatchez, L. (1999). Isolation and characterization of microsatellite loci in the walleye (Stizostedion vitreum), and cross-species amplification within the family Percidae. Molecular Ecology 8, 1960-1963. doi: 10.1046/ j.1365-294x.1999.00778-3.x 